\title{
Forecasting and management of gross domestic product
}

\author{
Viktor Oliinyk \\ Sumy State University, Ukraine \\ oliynyk.viktor@gmail.com
}

\author{
Serhiy Kozmenko \\ University of Social Science, Lod₹, Poland \\ University of Customs and Finance, Dnipro, Ukraine \\ kormenko.uabs@gmail.com
}

\begin{abstract}
Given that in order to predict the economic growth of a country, the dynamics of its GDP should be considered, and the forecast itself should be made taking into account the difference between actual and estimated figures, the article discusses the problems of GDP management and its optimal distribution. The use of averages to determine economic parameters is also analyzed. The correspondence of the regression formula and the Cauchy boundary value problem is considered. The problem of managing the GDP components to obtain the necessary characteristics of GDP growth is solved using Pontryagin Maximum Principle. As an example, several options of the optimal GDP distribution (constant prices, national currency) for China in 2016-2020 are considered. Numerical results are reported and adjusted for the discount factor. Based on the calculations, it is shown that in 2017-2018, GDP increases and in 2019-2020 it decreases.
\end{abstract}

Keywords: GDP, GDP growth, management function, Hamiltonian, forecasting, China.

JEL Classification: E27, C51

\section{INTRODUCTION}

Gross Domestic Product (GDP) is the main macroeconomic indicator of the state's overall wealth. There are several methods for calculating this indicator, that is, by income, by expenses, and by value added. Calculating GDP by income will be used to build and optimize the economic and mathematical model. When calculating the indicator, all non-production transactions are excluded, namely, public and private transfer transactions, securities transactions, etc. There exist real GDP and nominal GDP. The nominal GDP indicator depends on changes in price and income index. The indicator cannot be used both to compare the economic development of different countries and to explore the economic growth dynamics in one country at different time intervals. Therefore, for further analysis, the real GDP indicator will be used. According to the International Monetary Fund 2018 data, the global GDP calculated based on 
purchasing power parity (PPP) was USD 136.48 trillion. In particular, China accounts for $18.69 \%$ (USD 25,270 billion) of the global GDP, USA - 15.16\% (USD 20,494 billion), India - 7.77\% (USD 10,505 billion), Japan $-4.14 \%$ (USD 5594 billion), and Germany accounts for 3.22\% (USD 4,356 billion) of the global GDP. The first ten countries with the best economic indicators account for $61.62 \%$ of the total GDP, the twenty countries amount to $75.83 \%$, and the remaining 172 countries account for $24.17 \%$ of the global GDP by PPP.

In 2013-2017, the global average GDP growth rate was about $14 \%$; in 2018 , it was $3.0 \%$. In this context, the situation of China is interesting. It is suggested that in 2023, there will be a reduction in the Chinese economy growth rate to 5.5\%. Therefore, considering the GDP indicator as an object of management and optimization, the dynamics of the Chinese economy will be explored.

\section{LITERATURE REVIEW}

The GDP indicator is one of the most important attributes of the economic situation in any country. Many authors use this indicator in their studies. Deng and O'Brien (2016) reviewed various concepts and data related to the distribution of GDP per capita in China. They considered the time interval from the Han Dynasty to the Communist times. The authors concluded that the obtained numerical results, brought to the US dollar, do not reflect the values of the real indicator under study, namely, GDP per capita.

Barry et al. (2011) examined the growth rates of different economies. They use the GDP per capita indicator as an evaluation criterion. The historical data necessary for their study begin with 1957. Some of their main findings are as follows: the most likely slowdown in economic growth occurs in fear when the national currency is undervalued; the slowdown in country's economy occurs in 2005, at a time when per capita income reaches approximately USD 17,000 at constant international prices, while the economy's growth rate is falling by more than two points. As soon as the Chinese economy reaches this index, it is possible to slow down its growth rate.

In the pursuit of continuous high economic growth, these countries are facing serious environmental problems. India and China were the two largest countries with the greatest environmental impact in 2003.

Based on 2002-2016 data, Feng and Wang (2018) show that there is a negative relationship between GDP growth rates and the environmental performance index. However, nowhere but in Russia there is a strong correlation between environmental performance and GDP growth rates.

Mankiw et al. (1992) dealt with the application of the Solow growth model to study the economies with different levels of living standards. They proposed to introduce accumulation of physical and human capital into this model. The extended Solow model allows describing the dynamics of living standards more adequately in both poor and rich countries. They showed that the growth rate in the standards of living is more intense in poor countries.

Barro and Xavier (2004) analyzed various theories of economic growth. They consider the neoclassical Solow-Swan theory among the first. Further, issues related to the expansion of the indicators included in this model are discussed. Great attention is paid to the theory of endogenous growth. As the main indicators for building economic models, they suggest using the parameters of technical progress and the human factor.

Ali (2018) explored the impact of the tourism sector on GDP in Saudi Arabia. The author showed that in some types of tourist areas, costs exceed the income from their activities. The government of Saudi Arabia is currently taking measures to increase tourism revenues and thus to increase GDP.

Kubiszewski et al. (2013) suggested using the Genuine Progress Indicator (GPI) to assess the population well-being. They deduced their findings based on the studies conducted in 1950-2003 for 17 countries. They showed that during this period, GDP growth occurred, while the GPI index decreased from the 1978 level. They 
suggested assessing the real well-being of the population based on various indicators and considered that the GPI was not ideal, but that it rated the quality of economic well-being better than GDP.

Van den Bergh (2009) showed that GDP can be used as an indicator of population well-being. This question arose because many economists propose not to calculate this indicator to assess economic growth, and therefore this indicator is irrelevant. The author says that GDP continues to be one of the main indicators in society.

Kohli et al. (2012) propose a GDP growth model that includes the following parameters: fixed capital, labor, and total factor productivity (TFP). This model allows obtaining the estimates of economic situation in the country for the period up to 2050. Alternative scenarios of GDP dynamics for 185 countries of the world with different income levels are considered.

Mukhtarov et al. (2019) examined the dependence of non-oil GDP in Azerbaijan on the banking sector. As the factors of influence, bank loans and exchange rate were considered. In the course of long-term forecasting it was found that there was a positive trend between the resulting non-oil GDP and the selected factors.

Balcerzak (2016), Balcerzak \& Pietrzak (2016) conducted multiple-criteria analysis of the Quality of human capital in the EU countries at macroeconomic level and find a cointegration between global competitiveness, GDP growth and human capital development in the EU countries.

Siliverstovs (2012) suggested using a model that reconsiders the estimates of quarterly GDP growth rates. This model is tested using Swiss economy as an example and makes it possible to forecast quarterly GDP rates taking into account their initial estimates.

Kvasha et al. (2018) analyzed the existing methods of calculating GDP of Ukraine and offered an improved methodology. Their algorithm is based on the use of a mathematical apparatus for dynamic programming. It takes into account the shortcomings of the existing methods of calculating GDP and reflects the development trends of both world economic processes and socioeconomic processes taking place in Ukraine.

Sonko et al. (2018) proposed a mathematical model of Ukraine's GDP growth based on a study of two main economy sectors, namely, industry and agriculture. The main factors that have the most significant impact on GDP growth in Ukraine were identified.

Among other studies offering econometric models for the variables in question, one can also mention Dougherty, (1992), Goldberger (1990), Greene (1993), Pindyck and Rubinfeld (1991), Simionescu et al. (2016), Korauš et al. (2017), Kasperowicz (2014), Kaigorodova et al. (2018), Fashina et al. (2018).

\section{THEORETICAL BACKGROUND AND THE RESEARCH METHOD}

\subsection{ANALYSIS OF AVERAGES}

When modelling and optimizing economic indicators, it is necessary to obtain the distribution of the investigated factor taking into account a certain criterion (goal function). One of the criteria can be a characteristic average value corresponding to the phenomenon being investigated. In economic practice, a wide range of indicators are used, calculated as average values. The average values characterize the whole set of phenomena, which allows revealing the regularities inherent in mass phenomena that are imperceptible for single observations. The main condition for the scientifically-based use of averages is that the average is determined for aggregates. It consists of qualitatively homogeneous units.

The choice of the type of average is determined by the economic content of a certain indicator and the initial data. Let's consider the mean values belonging to the class of power averages: 


$$
\bar{X}=\sqrt[m]{\frac{\sum_{i=1}^{n} X_{i}^{m}}{n}},
$$

where

$\bar{X}$ is the average value of the phenomenon under study;

$\mathrm{m}$ is the exponent of the mean;

$X$ is a current value of the characteristic;

$\mathrm{n}$ is the number of features.

According to the value of the exponent $\mathrm{m}$, the following types of mean are given (see Table 1).

Table 1

Types of average values

\begin{tabular}{|c|c|c|c|}
\hline No. & Exponent $\mathbf{m}$ & Type of a power average & Formula \\
\hline 1 & -1 & Harmonic mean & $\bar{X}=n / \sum_{i=1}^{n}\left(1 / X_{i}\right)$ \\
\hline 2 & 0 & Geometric mean & $\bar{X}=\sqrt[n]{X_{1} X_{2} \ldots X_{n}}$ \\
\hline 3 & 1 & Arithmetic mean & $\bar{X}=\sum_{i=1}^{n} X_{i} / n$ \\
\hline 4 & 2 & Mean square & $\bar{X}=\sqrt{\frac{\sum_{i=1}^{n} X_{i}^{2}}{n}}$ \\
\hline 5 & 3 & Cubic mean & $\bar{X}=\sqrt[3]{\frac{\sum_{i=1}^{n} X_{i}^{3}}{n}}$ \\
\hline
\end{tabular}

For power averages, the medium majority rule is fulfilled: the power mean increases with the average exponent. Different types of power averages are used for different economic processes.

The arithmetic mean is used when the volume of the variable characteristic for the whole population is the sum of the characteristic values of its individual units.

The harmonic mean is a transformed form of the arithmetic mean and is identical to it. It is used when not variants are summable, but their reciprocals.

The geometric mean is used when the individual values of the characteristic are the relative values of the dynamics in the form of chain quantities.

The mean square and cubic mean values are used when there is a need to calculate the average size of a feature expressed in square or cubic units.

\subsection{FINDING THE BEST REGRESSION EQUATION}

In modeling monotone processes, when the amount of unknowns is insignificant, nine functions can be used (see Table 2). These associations have a special feature, namely, if separate values of variables $\mathrm{X}$ and $\mathrm{Y}$ satisfy one of the equations, the average values are also satisfied. For each of functions, there are 
characteristic averages, which can be arithmetic, geometric and harmonic means in this case. Correspondence of functions investigated and their average magnitudes is reduced in Table 2. In the table, $a, b=$ const .

Table 2

The aspect of the average magnitudes characterizing functions of a regression

\begin{tabular}{|c|l|c|c|}
\hline \multirow{2}{*}{ No. } & \multirow{2}{*}{ Function } & \multicolumn{2}{|c|}{ Characteristic averages } \\
\cline { 3 - 4 } & & $\bar{X}$ & $\bar{Y}$ \\
\hline 1 & $Y=a+b X$ & $\bar{X}=\sum_{i=1}^{n} X_{i} / n$ & $\bar{Y}=\sum_{i=1}^{n} Y_{i} / n$ \\
\hline 2 & $Y=a+b \ln X$ & $\bar{X}=\sqrt[n]{X_{1} X_{2} \ldots X_{n}}$ & $\bar{Y}=\sum_{i=1}^{n} Y_{i} / n$ \\
\hline 3 & $Y=a+b / X$ & $\bar{X}=n / \sum_{i=1}^{n}\left(1 / X_{i}\right)$ & $\bar{Y}=\sum_{i=1}^{n} Y_{i} / n$ \\
\hline 4 & $Y=a b^{X}$ & $\bar{X}=\sum_{i=1}^{n} X_{i} / n$ & $\bar{Y}=\sqrt[n]{Y_{1} Y_{2} \ldots Y_{n}}$ \\
\hline 5 & $Y=a X^{b}$ & $\bar{X}=\sqrt[n]{X_{1} X_{2} \ldots X_{n}}$ & $\bar{Y}=\sqrt[n]{Y_{1} Y_{2} \ldots Y_{n}}$ \\
\hline 6 & $Y=\exp (a+b / X)$ & $\bar{X}=n / \sum_{i=1}^{n}\left(1 / X_{i}\right)$ & $\bar{Y}=\sqrt[n]{Y_{1} Y_{2} \ldots Y_{n}}$ \\
\hline 7 & $Y=1 /(a+b X)$ & $\bar{X}=\sum_{i=1}^{n} X_{i} / n$ & $\bar{Y}=n / \sum_{i=1}^{n}\left(1 / Y_{i}\right)$ \\
\hline 8 & $Y=a+b X$ & $\bar{X}$ & $\bar{Y}$ \\
\hline 9 & $Y=a+b \ln X$ & $\bar{X}=\sum_{i=1}^{n} X_{i} / n$ & $\bar{Y}=\sum_{i=1}^{n} Y_{i} / n$ \\
\hline
\end{tabular}

The definition of one optimum function takes place in several stages. At the first stage, the necessary average magnitudes for variables $\mathrm{X}$ and $\mathrm{Y}$ are calculated. At the second stage, $X_{i}<\bar{X}<X_{i+1}$ dependence, by means of linear interpolation values is calculated.

$$
\hat{Y}_{i}=Y_{i}+\frac{Y_{i+1}-Y_{i}}{X_{i+1}-X_{i}}\left(\bar{X}-X_{i}\right)
$$

The third stage defines one of nine functions, which in the best way to describe input data. It is possible to use the following condition as a selection criterion:

$$
\left|\frac{\hat{Y}-\bar{Y}}{\hat{Y}}\right| \rightarrow \min
$$

The unknown constants, which are in the regression equation, are calculated using the least square method. This method is a basis for the regression analysis and consists of meeting a following condition for function of errors:

$$
S=\sum_{i=1}^{n}\left(Y_{i}-\hat{Y}_{i}\right)^{2} \rightarrow \min
$$


The determination of an extremum (4) for linear regression functions is reduced to a solution of linear system of the algebraic equations concerning $\mathrm{a}$ and $\mathrm{b}$ parameters. It is proved that this system has a unique solution and function of errors $\mathrm{S}$ reaches the minimum. In order to apply the method of least squares to all regression functions (Table 2), it is necessary to transform them beforehand. This transformation is their information in a linear aspect. Unknown constants, which are calculated from a condition (4), definitively define an aspect of the best regression equation.

It is possible to continue modeling of initial process and receive the concrete differential equation, which maps the phenomenon investigated. The constants entering into this differential equation are directly connected with the constants entering in the regression equation. Oliinyk (2018) considered some options of the best regression equation and the corresponding differential equation.

Quality of stochastic connection between variables $\mathrm{Y}$ and $\mathrm{X}$ (quality of the regression equations) can be estimated using the determination factor, which is calculated as follows:

$$
R^{2}=1-\sum_{i=1}^{n}\left(Y_{i}-\hat{Y}_{i}\right)^{2} / \sum_{i=1}^{n}\left(Y_{i}-\bar{Y}\right)^{2}
$$

Formula (5) shows how percent of the general variance of variable Y explains the regression equation investigated. It is possible to conclude that the problem of minimization of function of errors (4) using the least square method is equivalent to the problem of maximization of the determination factor (5). The more the value $R^{2}$ is closer to 1 , the better is the quality of the received model.

To test the importance of the regression equation as a whole, one can use various methods, for example, F - the Fisher's distributions. A certain parameter F is discovered for this purpose and compared to the table values of the Fisher distribution $F^{t}(m, n-m-1)$ at a set level of significance $\alpha$. To fulfill the conditions of (6), it is possible to conclude on the importance of the regression equation.

$$
F=\frac{R^{2}}{1-R^{2}} \frac{n-m-1}{m}>F^{t}
$$

The significance of the regression equation factors can be tested using a t-distribution and comparing the received values with table ones.

When the investigated magnitudes are distributed under the normal law, a variance of magnitude $\hat{Y}_{i}=\hat{Y}\left(X_{i}\right)$ will be calculated.

$$
D\left(\hat{Y}_{i}\right)=\left[\frac{1}{n}+\frac{\left(X_{i}-\bar{X}\right)^{2}}{\sum_{i=1}^{n}\left(X_{i}-\bar{X}\right)^{2}}\right] \frac{1}{n-m-1} \sum_{i=1}^{n}\left(Y_{i}-\hat{Y}_{i}\right)^{2} .
$$

The confidential zone of a prediction regression model can be received:

$$
\hat{Y}-t_{1-\alpha} \sqrt{D(\hat{Y})} \leq \tilde{Y} \leq \hat{Y}+t_{1-\alpha} \sqrt{D(\hat{Y})}
$$

where

$t_{1-\alpha}$ is a quantile of a distribution with n-m-1 degree of freedoms at a significance level of $\alpha$.

\section{PROBLEM STATEMENT}

Gross Domestic Product is one of the most common macroeconomic indicators (Mankiw, 2009). Consider the forecasting and management of this economic indicator over a time interval $\left[t_{1} ; t_{n}\right]$.

When calculating GDP by spending, one can have: 


$$
Y(t)=\sum_{i=1}^{4} \alpha_{i}(t) Y(t)=C(t)+I(t)+G(t)+N X(t)
$$

where

$\alpha_{i}(t)$ is a fractional component of GDP;

$C(t)=\alpha_{1}(t) Y(t)$ is consumer spending;

$I(t)=\alpha_{2}(t) Y(t)$ is investment spending;

$G(t)=\alpha_{3}(t) Y(t)$ is government purchases of goods and services;

$N X(t)=\alpha_{4}(t) Y(t)$ is spending on net exports.

Let's introduce GDP growth by the formula:

$$
T_{i}=\frac{Y_{i}-Y_{i-1}}{Y_{i-1}},(\mathrm{i}=2 \ldots \mathrm{n})
$$

The average GDP growth for the study period is:

$$
\bar{T}=\sqrt[n-1]{\frac{Y_{n}}{Y_{1}}}-1
$$

\subsection{SOLUTION TO THE PROBLEM BASED ON THE LINEAR PROGRAMMING METHOD (OPTION A)}

It is necessary to translate the system under study from the initial state to a given final state and to find the optimal distribution of GDP growth by years. At the same time, the average GDP growth should be maximum when certain restrictions are met. As a goal function, one can use the geometric mean value of GDP growth in the period under study.

$$
\begin{gathered}
\frac{1}{n-1} \prod_{i=2}^{n} T_{i} \rightarrow \max \\
\left\{\begin{array}{c}
Y_{i} \geq Y_{i-1},(i=\overline{2, n}) \\
T_{i} \geq T_{i}^{*},(i=\overline{2, n}) \\
Y_{i} \geq 0,(i=\overline{1, n})
\end{array}\right.
\end{gathered}
$$

where $T_{i}^{*}$ is a minimum value of GDP growth.

Let us consider the analytical solution of the optimal GDP distribution by years (13) on the interval $\left[t_{1}=1 ; t_{5}=5\right]$, corresponding to the solution of problem (12): 


$$
\begin{aligned}
& Y_{1}^{*}=Y_{1} \\
& Y_{2}^{*}=Y_{1} \sqrt[4]{\frac{Y_{5}}{Y_{1}}} \\
& Y_{3}^{*}=\frac{Y_{2}^{*} Y_{2}^{*}}{Y_{1}} \\
& Y_{4}^{*}=Y_{2}^{*} \sqrt{\frac{Y_{5}}{Y_{1}}} \\
& Y_{5}^{*}=Y_{5}
\end{aligned}
$$

Optimal distribution of GDP $Y_{i}^{*}$ by years (13) makes it possible to obtain a uniform GDP growth $T_{i}$ on the investigated interval $\left[t_{1}=1 ; t_{5}=5\right]$ in the analytical form. A numerical solution to this problem under more general constraints can be obtained from the solution of the equation system (12).

The optimal solution in the form of (12) and (13) allows for obtaining the general distribution of GDP by years. This does not take into account the optimal distribution by the components of GDP (9). Let's consider the problem of managing GDP taking into account the optimality of its components.

\subsection{THE PROBLEM STATEMENT (OPTION B)}

It is necessary to translate the system under investigation from the initial state $Y_{1}$ to a given final state $Y_{n}$ on the interval $\left[t_{1} ; t_{n}\right]$ and find the optimal distribution of GDP growth by years when the integral optimality condition is fulfilled. One method for solving the management problem is the Pontryagin maximum principle (Pontryagin et al., 1983; Arutyunov et al., 2006; Shell, 1969).

The problem statement can be represented as described below.

The equations of the system situation:

$$
\left\{\begin{array}{l}
\frac{d I}{d t}=\mu_{1} I+U_{1}(t) \\
\frac{d G}{d t}=\mu_{2} G+U_{2}(t) \\
\frac{d(N X)}{d t}=\frac{\mu_{3}}{t} \\
\frac{d C}{d t}=\mu_{4} C+U_{3}(t) \\
Y(t)=C(t)+I(t)+G(t)+N X(t)
\end{array}\right.
$$

Initial conditions:

End conditions:

$$
\begin{aligned}
& I\left(t_{1}\right)=I_{1} \\
& G\left(t_{1}\right)=G_{1} \\
& N X\left(t_{1}\right)=N X_{1} \\
& C\left(t_{1}\right)=C_{1}
\end{aligned}
$$


Management function represented as:

$$
\begin{aligned}
& I\left(t_{n}\right)=I_{n} \\
& G\left(t_{n}\right)=G_{n} \\
& N X\left(t_{n}\right)=N X_{n} \\
& C\left(t_{n}\right)=C_{n}
\end{aligned}
$$

$$
\begin{aligned}
& U_{1}(t)=v_{1}(t) I \\
& U_{2}(t)=v_{2}(t) G \\
& U_{3}(t)=v_{3}(t)(Y-I-G-N X) .
\end{aligned}
$$

Optimality condition can be represented as:

$$
\int_{t_{1}}^{t_{n}} \exp (-\delta t)\left\{\exp \left(-v_{1} I\right)+\exp \left(-v_{2} G\right)+\exp \left(-v_{3} C\right)\right\} d t+a_{1} I_{n}+a_{2} G_{n}+a_{3} N X_{n}+a_{4} C_{n} \rightarrow \max
$$

where $\delta$ is a discount coefficient.

\subsection{THE PROBLEM SOLUTION}

The Hamiltonian function has been written:

$$
\begin{aligned}
H(t) & =\Psi_{1}\left\{\mu_{1} I+v_{1} I\right\}+\Psi_{2}\left\{\mu_{2} G+v_{2} G\right\}+\Psi_{3} \mu_{3} / t+\Psi_{4}\left\{\mu_{4} C+v_{3}(Y-I-N X-G\}+\right. \\
& +\exp (-\delta t)\left\{\exp \left(-v_{1} I\right)+\exp \left(-v_{2} G\right)+\exp \left(-v_{3} C\right)\right\}
\end{aligned}
$$

where $\Psi_{i}(t)$ is an auxiliary function that satisfies the equation:

$$
\left\{\begin{array}{c}
\frac{d \Psi_{1}}{d t}=-\Psi_{1} \mu_{1} \\
\frac{d \Psi_{2}}{d t}=-\Psi_{2} \mu_{2} \\
\frac{d \Psi_{3}}{d t}=0 \\
\frac{d \Psi_{4}}{d t}=-\Psi_{4} \mu_{4}
\end{array}\right.
$$

For the auxiliary function, transversality is carried out:

$$
\Psi_{i}\left(t_{n}\right)=-a_{i}
$$

The Hamiltonian extremum will be found using the management parameter:

$$
\left\{\begin{array}{l}
\frac{d H}{d v_{1}}=\Psi_{1} I-I \exp \left(-\delta t-v_{1} I\right)=0 \\
\frac{d H}{d v_{2}}=\Psi_{2} G-G \exp \left(-\delta t-v_{2} G\right)=0 . \\
\frac{d H}{d v_{3}}=\Psi_{4} C-C \exp \left(-\delta t-v_{3} C\right)=0
\end{array}\right.
$$

To solve the problem, it is necessary to find the solutions to the obtained system of equations (14), (20), and (22) under additional conditions (15), (16), (18), and (21). The solution found shows the distribution of GDP by years in the period under study, provided that the components of GDP are optimally distributed according to the relationship (18). 


\section{RESULTS}

Let's consider the options for the China's GDP distribution by years for different models. As an example, historical 1997-2015 data and forecast data for 2016-2020 (Economy Watch, 2015) will be used. Table 3 presents the numerical values of GDP (constant prices, national currency) for China, as well as its components for the historical period. In this formulation, the model problem is considered. To obtain real values of GDP components, it is necessary to use more accurate statistics.

Table 3

The GDP values (constant prices, national currency) and their components for China for 1997-2015

\begin{tabular}{|c|l|c|c|c|c|c|}
\hline No. & \multicolumn{1}{|c|}{ Characteristic } & GDP, Y & Investment, I & $\begin{array}{c}\text { General } \\
\text { government } \\
\text { total } \\
\text { expenditure, G }\end{array}$ & $\begin{array}{c}\text { Current } \\
\text { account } \\
\text { balance, NX } \mathbf{N X}\end{array}$ & $\begin{array}{l}\text { Consumer } \\
\text { spending, } \\
\text { C }\end{array}$ \\
\hline 1 & Arithmetic mean, $\bar{X}$ & 30506,385 & 13126,522 & 6950,412 & 1159,828 & 9269,623 \\
\hline 2 & Standard deviation, $\sigma_{X}$ & 15538,722 & 7717,498 & 5357,448 & 893,852 & 2269,218 \\
\hline
\end{tabular}

For further calculations, one can normalize the variables using the formula:

$$
\tilde{X}_{i}=\frac{X_{i}-\overline{X_{i}}}{\sigma_{x_{i}}}
$$

where

$X_{i}$ is the current value of a variable;

$\overline{X_{i}}$ is a mean value of a variable;

$\sigma_{x_{i}}$ is standard deviation of a variable.

Table 4 presents GDP (constant prices, national currency) and the components for China for the period of 2016-2020 (Economy Watch, 2015).

Table 4

Forecasting GDP (constant prices, national currency) for China

\begin{tabular}{|c|c|c|c|c|c|c|}
\hline$t$ & Year & GDP, Y (\%) & Investment, I (\%) & $\begin{array}{c}\text { General } \\
\text { government total } \\
\text { expenditure, G } \\
(\%) \\
\end{array}$ & $\begin{array}{c}\text { Current account } \\
\text { balance, NX } \\
(\%)\end{array}$ & $\begin{array}{c}\text { Consumer } \\
\text { spending, } \\
\text { C }(\%)\end{array}$ \\
\hline \multirow{2}{*}{1} & \multirow{2}{*}{2016} & 63053,370 & 26369,550 & 17880,044 & 1641,910 & 17161,866 \\
\hline & & 100 & 41,821 & 28,357 & 2,604 & 27,218 \\
\hline \multirow{2}{*}{2} & \multirow{2}{*}{2017} & 66962,680 & 27352,246 & 18987,938 & 1379,431 & 19243,065 \\
\hline & & 100 & 40,847 & 28,356 & 2,06 & 28,737 \\
\hline \multirow{2}{*}{3} & \multirow{2}{*}{2018} & 70980,440 & 28434,764 & 20011,515 & 1029,216 & 21504,944 \\
\hline & & 100 & 40,06 & 28,193 & 1,45 & 30,297 \\
\hline \multirow[b]{2}{*}{4} & \multirow[b]{2}{*}{2019} & 75239,270 & 29477,994 & 20989,499 & 704,240 & 24067,538 \\
\hline & & 100 & 39,179 & 27,897 & 0,936 & 31,988 \\
\hline \multirow{2}{*}{5} & \multirow{2}{*}{2020} & 79753,630 & 30398,894 & 22012,002 & 527,171 & 26815,563 \\
\hline & & 100 & 38,116 & 27,6 & 0,661 & 33,623 \\
\hline
\end{tabular}

Given the Table 4 data, one can find the optimal GDP growth, using formulas (12) and (13). For options 1 and 2, the calculation is carried out for the indicator $T_{i}^{*}=6 \%$ - the minimum value of GDP growth. Option 1 corresponds to the data presented in Economy Watch (2015). Option 2 corresponds to 
the calculations according to formula (13). Option 3 takes into account the forecast of GDP growth in 2017 at $6.6 \%$. Table 5 presents the GDP distribution (constant prices, national currency) for China and GDP growth for the period under study for various optimal options.

Table 5

GDP distribution (constant prices, national currency) for China

\begin{tabular}{|c|c|c|c|c|c|c|c|}
\hline \multirow[b]{2}{*}{$t$} & \multirow[b]{2}{*}{ Year } & \multicolumn{2}{|c|}{ Option 1} & \multicolumn{2}{|c|}{ Option 2} & \multicolumn{2}{|c|}{ Option 3} \\
\hline & & GDP & $\begin{array}{c}\text { GDP } \\
\text { growth, \% }\end{array}$ & GDP & $\begin{array}{c}\text { GDP } \\
\text { growth, \% }\end{array}$ & GDP & $\begin{array}{c}\text { GDP } \\
\text { growth, } \\
\%\end{array}$ \\
\hline 1 & 2016 & 63053,370 & - & 63053,370 & - & 63053,370 & - \\
\hline 2 & 2017 & 66962,680 & 6,200 & 66868,082 & 6,050 & 67214,892 & 6,600 \\
\hline 3 & 2018 & 70980,440 & 6,000 & 70913,578 & 6,050 & 71158,496 & 5,867 \\
\hline 4 & 2019 & 75239,270 & 6,000 & 75203,815 & 6,050 & 75333,470 & 5,867 \\
\hline 5 & 2020 & 79753,630 & 6,000 & 79753,630 & 6,050 & 79753,630 & 5,867 \\
\hline \multicolumn{2}{|c|}{ Geometric mean } & - & 6,049 & - & 6,050 & - & 6,042 \\
\hline
\end{tabular}

The optimal GDP distribution presented in Table 5 does not reflect the optimal distribution of GDP components for the period 2016-2020. Let's find the GDP distribution (constant prices, national currency) for China, taking into account the optimal management of the GDP components (14)-(18). Calculation will be made for the standardized indicators:

$$
\tilde{Y}=\frac{Y-\bar{Y}}{\sigma_{Y}} ; \tilde{I}=\frac{I-\bar{I}}{\sigma_{Y}} ; \tilde{N} X=\frac{N X-\overline{N X}}{\sigma_{Y}} ; \tilde{C}=\frac{C-\bar{C}}{\sigma_{Y}}
$$

Let's consider several variants of optimal management of the GDP components (constant prices, national currency) for China. The initial and final values of the variables are: $\tilde{I}_{1}=0,8522 ; \tilde{G}_{1}=0,7034$; $\tilde{N} X_{1}=0,0310 ; \tilde{C}_{1}=0,5079 ; \tilde{I}_{5}=1,111 ; \tilde{G}_{5}=0,969 ; \tilde{N} X_{5}=-0,041 ; \tilde{C}_{5}=1,129$. Table 6 shows the system parameter values for various control options.

Table 6

System parameters under study

\begin{tabular}{|c|c|c|c|c|c|}
\hline No. & Parameter & Option 4 & Option 5 & Option 6 & Option 7 \\
\hline 1 & $\mu_{1}$ & 0,0664 & $-0,0439$ & $-0,0439$ & 0,0403 \\
\hline 2 & $\mu_{2}$ & 0,08 & 0,0079 & $-0,0022$ & 0,0508 \\
\hline 3 & $\mu_{3}$ & $-0,0445$ & $-0,0445$ & $-0,0445$ & $-0,0445$ \\
\hline 4 & $\mu_{4}$ & 0,1998 & 0,0373 & 0,0373 & 0,0369 \\
\hline 5 & $a_{1}$ & 0 & $-0,978$ & $-0,978$ & $-0,775$ \\
\hline 6 & $a_{2}$ & 0 & $-0,927$ & $-0,938$ & $-0,759$ \\
\hline 7 & $a_{3}$ & 0 & 0 & 0 & 0 \\
\hline 8 & $a_{4}$ & 0 & $-0,817$ & $-0,817$ & $-0,706$ \\
\hline 9 & $\delta$ & 0 & 0 & 0 & 0,05 \\
\hline
\end{tabular}


Table 7 represent the distribution of control parameters over the investigated interval of 2016-2020.

Table 7

Values of distribution parameters

\begin{tabular}{|c|c|c|c|c|c|c|c|c|c|c|c|c|c|}
\hline \multirow{2}{*}{$\mathbf{t}$} & \multirow{2}{*}{ Year } & \multicolumn{3}{|c|}{ Option 4} & \multicolumn{3}{|c|}{ Option 5} & \multicolumn{3}{|c|}{ Option 6} & \multicolumn{3}{|c|}{ Option 7} \\
\hline & & $v_{1}$ & $v_{2}$ & $v_{3}$ & $v_{1}$ & $v_{2}$ & $v_{3}$ & $v_{1}$ & $v_{2}$ & $v_{3}$ & $v_{1}$ & $v_{2}$ & $v_{3}$ \\
\hline 1 & 2016 & 0 & 0 & 0 & 0,233 & 0,062 & 0,103 & 0,233 & 0,103 & 0,103 & 0,052 & 0,032 & 0,297 \\
\hline 2 & 2017 & 0 & 0 & 0 & 0,156 & 0,069 & 0,15 & 0,156 & 0,091 & 0,15 & 0,037 & 0,031 & 0,204 \\
\hline 3 & 2018 & 0 & 0 & 0 & 0,103 & 0,073 & 0,173 & 0,103 & 0,081 & 0,173 & 0,025 & 0,029 & 0,15 \\
\hline 4 & 2019 & 0 & 0 & 0 & 0,06 & 0,076 & 0,181 & 0,06 & 0,073 & 0,181 & 0,014 & 0,028 & 0,113 \\
\hline 5 & 2020 & 0 & 0 & 0 & 0,02 & 0,078 & 0,178 & 0,02 & 0,066 & 0,178 & 0,005 & 0,027 & 0,087 \\
\hline
\end{tabular}

Tables 8-11 show the GDP distribution (constant prices, national currency) for China for various management options.

Table 8

GDP distribution (constant prices, national currency) for China (Option 4)

\begin{tabular}{|c|c|c|c|c|c|c|c|}
\hline$t$ & Year & GDP, Y ( $\%)$ & $\begin{array}{c}\text { GDP growth, } \\
\%\end{array}$ & $\begin{array}{c}\text { Investment, I } \\
(\%)\end{array}$ & $\begin{array}{c}\text { General } \\
\text { government } \\
\text { total } \\
\text { expenditure, } \\
\text { G }(\%)\end{array}$ & $\begin{array}{c}\text { Current } \\
\text { account } \\
\text { balance, NX } \\
(\%)\end{array}$ & $\begin{array}{c}\text { Consumer } \\
\text { spending, C } \\
(\%)\end{array}$ \\
\hline \multirow{2}{*}{1} & \multirow{2}{*}{2016} & 63044,849 & - & 26365,512 & 17874,133 & 1641,910 & 17163,294 \\
\hline & & 100 & - & 41,820 & 28,351 & 2,604 & 27,224 \\
\hline \multirow{2}{*}{2} & \multirow{2}{*}{2017} & 66136,674 & 4,904 & 27282,297 & 18790,918 & 1159,828 & 18903,631 \\
\hline & & 100 & - & 41,251 & 28,412 & 1,754 & 28,583 \\
\hline \multirow{2}{*}{3} & \multirow{2}{*}{2018} & 69928,122 & 5,733 & 28245,698 & 19769,857 & 880,131 & 21032,436 \\
\hline & & 100 & - & 40,392 & 28,272 & 1,259 & 30,077 \\
\hline \multirow{2}{*}{4} & \multirow{2}{*}{2019} & 74449,890 & 6,466 & 29286,792 & 20842,029 & 678,128 & 23642,941 \\
\hline & & 100 & - & 39,338 & 27,995 & 0,911 & 31,757 \\
\hline \multirow{2}{*}{5} & \multirow{2}{*}{2020} & 79733,055 & 7,096 & 30390,041 & 22007,433 & 522,741 & 26812,840 \\
\hline & & 100 & - & 38,115 & 27,601 & 0,656 & 33,628 \\
\hline \multicolumn{2}{|c|}{$\begin{array}{c}\text { Geometric } \\
\text { mean }\end{array}$} & - & 5,993 & - & - & - & - \\
\hline
\end{tabular}

Table 9

GDP distribution (constant prices, national currency) for China (Option 5)

\begin{tabular}{|c|c|c|c|c|c|c|c|}
\hline$t$ & Year & GDP, Y ( $(\%)$ & GDP growth, & $\begin{array}{c}\text { Investment, I } \\
(\%)\end{array}$ & $\begin{array}{c}\text { General } \\
\text { government total } \\
\text { expenditure, G (\%) }\end{array}$ & $\begin{array}{c}\text { Current } \\
\text { account } \\
\text { balance, NX } \\
(\%)\end{array}$ & $\begin{array}{c}\text { Consumer } \\
\text { spending, C } \\
(\%)\end{array}$ \\
\hline \multirow{2}{*}{1} & \multirow{2}{*}{2016} & 63044,849 & - & 26365,512 & 17874,133 & 1641,910 & 17163,294 \\
\hline & & 100 & - & 41,820 & 28,351 & 2,604 & 27,224 \\
\hline \multirow{2}{*}{2} & \multirow{2}{*}{2017} & 66929,149 & 6,161 & 28478,779 & 18713,224 & 1159,828 & 18577,318 \\
\hline & & 100 & - & 42,551 & 27,960 & 1,733 & 27,757 \\
\hline \multirow{2}{*}{3} & \multirow{2}{*}{2018} & 71031,371 & 6,129 & 29830,647 & 19676,625 & 880,131 & 20643,968 \\
\hline & & 100 & - & 41,996 & 27,701 & 1,239 & 29,063 \\
\hline \multirow{2}{*}{4} & \multirow{2}{*}{2019} & 75288,981 & 5,994 & 30452,196 & 20779,874 & 678,128 & 23378,783 \\
\hline & & 100 & - & 40,447 & 27,600 & 0,901 & 31,052 \\
\hline \multirow{2}{*}{5} & \multirow{2}{*}{2020} & 79733,055 & 5,903 & 30390,041 & 22007,433 & 522,741 & 26812,840 \\
\hline & & 100 & - & 38,115 & 27,601 & 0,656 & 33,628 \\
\hline \multicolumn{2}{|c|}{$\begin{array}{c}\text { Geometri } \\
\mathrm{c} \text { mean }\end{array}$} & - & 6,046 & - & - & - & - \\
\hline
\end{tabular}


GDP distribution (constant prices, national currency) for China (Option 6)

\begin{tabular}{|c|c|c|c|c|c|c|c|}
\hline$t$ & Year & GDP, Y (\%) & GDP growth, & $\begin{array}{c}\text { Investment, } \\
\text { I }(\%)\end{array}$ & $\begin{array}{c}\text { General government } \\
\text { total expenditure, G } \\
(\%)\end{array}$ & $\begin{array}{l}\text { Current account } \\
\text { balance, NX (\%) }\end{array}$ & $\begin{array}{c}\text { Consumer } \\
\text { spending, C } \\
(\%)\end{array}$ \\
\hline \multirow{2}{*}{1} & \multirow{2}{*}{2016} & 63044,849 & - & 26365,512 & 17874,133 & 1641,910 & 17163,294 \\
\hline & & 100 & - & 41,820 & 28,351 & 2,604 & 27,224 \\
\hline \multirow{2}{*}{2} & \multirow{2}{*}{2017} & 67177,768 & 6,556 & 28478,779 & 18961,844 & 1159,828 & 18577,318 \\
\hline & & 100 & - & 42,393 & 28,226 & 1,727 & 27,654 \\
\hline \multirow{2}{*}{3} & \multirow{2}{*}{2018} & 71373,223 & 6,245 & 29830,647 & 20018,477 & 880,131 & 20643,968 \\
\hline & & 100 & - & 41,795 & 28,048 & 1,233 & 28,924 \\
\hline \multirow{2}{*}{4} & \multirow{2}{*}{2019} & 75537,600 & 5,835 & 30452,196 & 21028,494 & 678,128 & 23378,783 \\
\hline & & 100 & - & 40,314 & 27,838 & 0,898 & 30,950 \\
\hline \multirow{2}{*}{5} & \multirow{2}{*}{2020} & 79733,055 & 5,554 & 30390,041 & 22007,433 & 522,741 & 26812,840 \\
\hline & & 100 & - & 38,115 & 27,601 & 0,656 & 33,628 \\
\hline \multicolumn{2}{|c|}{$\begin{array}{l}\text { Geometri } \\
\mathrm{c} \text { mean }\end{array}$} & - & 6,035 & - & - & - & - \\
\hline
\end{tabular}

Table 11

GDP distribution (constant prices, national currency) for China (Option 7)

\begin{tabular}{|c|c|c|c|c|c|c|c|}
\hline$t$ & Year & $\begin{array}{c}\text { GDP,Y } \\
(\%)\end{array}$ & $\begin{array}{c}\text { GDP } \\
\text { growth, \% }\end{array}$ & $\begin{array}{c}\text { Investment, I } \\
(\%)\end{array}$ & $\begin{array}{c}\text { General } \\
\text { government total } \\
\text { expenditure, } G(\%)\end{array}$ & $\begin{array}{l}\text { Current } \\
\text { account } \\
\text { balance, } \\
\text { NX }(\%)\end{array}$ & $\begin{array}{l}\text { Consumer } \\
\text { spending, } \\
\text { C ( }(\%)\end{array}$ \\
\hline \multirow{2}{*}{1} & \multirow{2}{*}{2016} & 63044,849 & - & 26365,512 & 17874,133 & 1641,910 & 17163,294 \\
\hline & & 100 & - & 41,820 & 28,351 & 2,604 & 27,224 \\
\hline \multirow{2}{*}{2} & \multirow{2}{*}{2017} & 67255,462 & 6,679 & 27530,916 & 18821,995 & 1159,828 & 19742,722 \\
\hline & & 100 & - & 40,935 & 27,986 & 1,725 & 29,355 \\
\hline \multirow{2}{*}{3} & \multirow{2}{*}{2018} & 71513,072 & 6,331 & 28603,088 & 19816,474 & 880,131 & 22213,378 \\
\hline & & 100 & - & 39,997 & 27,710 & 1,231 & 31,062 \\
\hline \multirow{2}{*}{4} & \multirow{2}{*}{2019} & 75677,449 & 5,823 & 29550,950 & 20873,107 & 678,128 & 24575,264 \\
\hline & & 100 & - & 39,049 & 27,582 & 0,896 & 32,474 \\
\hline \multirow{2}{*}{5} & \multirow{2}{*}{2020} & 79733,055 & 5,359 & 30390,041 & 22007,433 & 522,741 & 26812,840 \\
\hline & & 100 & - & 38,115 & 27,601 & 0,656 & 33,628 \\
\hline \multicolumn{2}{|c|}{$\begin{array}{c}\text { Geometric } \\
\text { mean }\end{array}$} & - & 6,027 & - & - & - & - \\
\hline
\end{tabular}

\section{DISCUSSION}

Many economists criticize GDP as an indicator of the population economic well-being and economic growth. Kubiszewski et al. (2013) analyze the dynamics of global GDP for 17 countries, which account for $59 \%$ of world GDP. The authors conclude that it is necessary to better consider the welfare of the population, not only in terms of GDP growth. They suggest using the GPI indicator, which, in their opinion, better estimates the real welfare of the population.

Van den Bergh (2009) prove that GDP continues to be one of the main indicators of the country's economic development. Barro and Xavier (2004) examine the neoclassical growth theory. They compare endogenous growth theory with models of endogenous technological progress. Despite the criticism of GDP as an economic growth criterion, economists still use it in their calculations (Kohli et al., 2012; Barry et al., 2011; Mankiw et al., 1992; Siliverstovs, 2012). 
To forecast the country's economic growth, it is necessary to assess the dynamics of GDP for a certain period. This forecast should be carried out taking into account the difference between actual and estimated figures. To obtain true results, it is critical to make timely adjustments to economic indicators. To adequately estimate the GDP index, it is essential to consider different scenarios for its distribution. The optimal trajectory of the GDP movement from a given initial state to a given final state can be obtained using mathematical optimization methods. One of the components of GDP can be used as an optimization criterion.

\section{CONCLUSION}

In the article, the indicator of the country's economic development in the form of GDP is considered. It is shown that the optimal distribution of GDP components can be obtained using several methods. When predicting GDP growth, one can use the values of geometric mean values. At the same time, GDP growth over the years is assumed constant throughout the review period. Forecasting the change in the GDP indicator for future periods can also be carried out using linear programming. To implement the optimal forecasting by the GDP components taking into account the objective function, it is necessary to use other methods. As the integral objective function, the value of the minimum aggregate indicator of the three components of GDP is used for the forecast period. The Pontryagin maximum principle was used to solve the problem. Several variants of the optimal control of the GDP components are given, which satisfy the initial and final parameters of the system. As an example, the optimal distribution of GDP (constant prices, national currency) for China in the 2016-2020 interval is considered. Numerical results are presented when adjusted for the discount factor. It is shown that, taking into account the discounting factor in 2017-2018, GDP growth increases, and in 2019-2020 it decreases. The approach proposed in the paper allows for an optimal redistribution of the GDP components when the necessary extremum of the objective function is satisfied.

\section{REFERENCES}

Ali, A. (2018). Travel and tourism: growth potentials and contribution to the GDP of Saudi Arabia. Problems and Perspectives in Management, 16(1), 417- 427. doi:10.21511/ppm.16(1).2018.39.

Arutyunov, A. V., Magaril-Il'yaev, G. G., \& Tihomirov, V. M. (2006). Pontryagin Maximum Principle. Proofs and applications. Moscow: Factorial Press.

Balcerzak, A. P., \& Pietrzak, M. B. (2016). Quality of institutions for knowledge-based economy within new institutional economics framework. multiple criteria decision analysis for European countries in the years 20002013. Economics and Sociology, 9(4), 66-81. doi:10.14254/2071-789X.2016/9-4/4

Balcerzak, A. P. (2016). Multiple-criteria evaluation of quality of human capital in the European Union countries. Economics and Sociology, 9(2), 11-26. doi:10.14254/2071-789X.2016/9-2/1

Barro, R. J., \& Xavier, Sala-i-Martin (2004). Economic growth (2nd ed.). Cambridge: MIT Press. Retrieved from https://mitpress.mit.edu/books/economic-growth.

Barry, E, Donghyun, P., \& Kwanho, S. (2011). When fast growing economies slow down: International evidence and implications for China (NBER Working Paper Series, No. 16919). Retrieved from http://www.nber.org/papers/w16919.

Deng, K., \& O'Brien, P. (2016). China’s GDP Per Capita from the Han Dynasty to Communist Times (Economic History Working Paper Series 229). Retrieved from http:/ / eprints.lse.ac.uk/64857/1/WP229.pdf.

Dougherty, C. (1992). Introduction to Econometrics. Oxford University Press. Retrieved from https://global.oup.com/academic/product/introduction-to-econometrics9780199676828 ?cc $=$ us\&lang $=$ en\&. 
Economy Watch. (2015). Econ Stats: The Economic Statistics and Indicators Database. Retrieved from http://www.economywatch.com/economic-statistics/.

Fashina, O. A., Asaleye, A. J., Ogunjobi, J. O., \& Lawal, A. I. (2018). Foreign aid, human capital and economic growth nexus: Evidence from Nigeria. Journal of International Studies, 11(2), 104-117.

Feng, J. and Wang, W. (2018). Fund performance-flow relationship and the role of institutional reform. Investment Management and Financial Innovations, 15(1), 311-327. doi:10.21511/imfi.15(1).2018.26

Goldberger, A. A. (1990). Course in Econometrics Cambridge, MA: Harvard University Press. Retrieved from http:/ /www.hup.harvard.edu/catalog.php?isbn=9780674175440.

Greene, W. (2012). Econometric Analysis (7th ed.). Pearson.

Kaigorodova, G., Alyakina, D., Pyrkova, G., Mustafina, A., \& Trynchuk, V. (2018). Investment activity of insurers and the state economic growth. Montenegrin Journal of Economics, 14(4), 109-123.

Kasperowicz, R. (2014). Economic growth and energy consumption in 12 european countries: A panel data approach. Journal of International Studies, 7(3), 112-122. doi:10.14254/2071-8330.2014/7-3/10

Kohli, H. A., Szyf, Y. A., \& Arnold, D. (2012). Construction and Analysis of a Global GDP Growth Model for 185 Countries through 2050. Global Journal of Emerging Market Economies, 4(2), 91-153. DOI: https://doi.org/10.1177/0974910112467121.

Korauš, A., Simionescu, M., Bilan, Y., \& Schönfeld, J. (2017). The impact of monetary variables on the economic growth and sustainable development: Case of selected countries. Journal of Security and Sustainability Issues, 6(3), 384-390.

Kubiszewski, I., Costanza, R., Franco, C., Lawn, P., Talberth, J., Jackson, T., \& Aylmer, C. (2013). Beyond GDP: Measuring and Achieving Global Genuine Progress, Ecological Economics, 93, 57-68. https://doi.org/10.1016/j.ecolecon.2013.04.019.

Kvasha, S., Davydenko, N., Pasichnyk, Y., Viatkina, T., \& Wasilewska, N. (2018). GDP modelling: assessment of methodologies and peculiarities of its usage in Ukraine. Problems and Perspectives in Management, 16(4), 186-200. doi:10.21511/ppm.16(4).2018.16.

Mankiw, N. G. (2009). Macroeconomics (7th ed.). Worth Publishers.

Mankiw, N. G., Romer, D., \& Weil, D. N. (1992). A Contribution to the empirics of economic growth. The Quarterly Journal of Economics, 107(2), 407-437. https://doi.org/10.2307/2118477.

Mukhtarov, S., Humbatova, S., \& Seyfullayev, İ. (2019). The impact of bank credits on non-oil GDP: evidence from Azerbaijan. Banks and Bank Systems, 14(2), 120-127. doi:10.21511/bbs.14(2).2019.10.

Oliinyk, V. (2018). Optimal Management of GDP Components. Journal of Advanced Research in Law and Economics, IX, Spring, 2(32), 603-614. DOI:10.14505/jarle.v9.2(32).24.

Pindyck, R., \& Rubinfeld, D. (1991). Econometric Models and Economic Forecasts (3rd ed.). McGraw.

Pontryagin, L. S, Boltyanskii, V. G., Gamkrelidze, R. V., \& Mishchenko, E. F. (1983). The Mathematical Theory of Optimal Processes. Nauka (in Russian). Retrieved from https:/ / scholar.google.com/scholar_lookup?publication_year=1986\&author=L.S.+Pontryagin\&author=V.G .+Boltyanski $\backslash u\{i\} \&$ author=R.V.+Gamkrelidze\&author=E.F.+Mishchenko\&title $=$ The + Mathematical + Theo ry+of+Optimal+Processes, + Edited +and +with $+\mathrm{a}+$ Preface+by+R.+V.+Gamkrelidze.

Shell, K. (1969). Application of Pontryagin's Maximum Principle to Economics / Mathematical System Theory and Economics (pp. 241-292) [Lecture Notes in Operations Research and Mathematical Economics, 11]. Berlin: Springer.

Siliverstovs, B. (2012). Are GDP Revisions Predictable? Evidence for Switzerland. Applied Economics Quarterly, 58(4), 299-326. https://doi.org/10.3790/aeq.58.4.299.

Simionescu, M., Ciuiu, D., Bilan, Y., \& Strielkowski, W. (2016). GDP and net migration in some eastern and southeastern countries of Europe. A panel data and Bayesian approach. Montenegrin Journal of Economics, 12(2), 161175.

Sonko, Y., Lazebna, I., \& Lebedeva, L. (2018). Material production and GDP in Ukraine: theoretical concept and financial assessment. Investment Management and Financial Innovations, 15(2), 51-59. doi: 10.21511/imfi.15(2).2018.05.

Van den Bergh, J. C. J. M. J. (2009). The GDP paradox. Journal of Economic Psychology, 30, 117-135. http://dnr.maryland.gov/mdgpi/Documents/GDP_Paradox.pdf. 